the grants which had enabled him to carry out research in meteorology at the Imperial College of Science and Technology in London for three years; and he stressed the great benefit which could be conferred on science by the endowment of scholarships in meteorology which would permit postgraduate students to study meteorology in Great Britain. Dr. Keen's presidential address dealt with the subject of "What happens to the Rain ?" An annual rainfall of $30 \mathrm{in}$. means that 3,000 tons of water fall on an acre of land. In the course of the year this all disappears, by run-off, evaporation, transpiration through vegetation, and by downward percolation. The relative importance of these factors in British and overseas conditions was discussed. It is only in recent years that the true picture of the movement of water in the soil has been built up. In consequence, some of the traditional practices need revision, while others now have a different explanation. The new work has also clarified some of the concepts used in hydrology.

\section{Opening of Griffith Institute of Archæology, Oxford}

THE Griffith Institute of Archæology, an extension of the Ashmolean Museum of the University of Oxford made possible by the generous benefaction of the late Prof. F. Ll. and Mrs. Griffith, was declared open on January 21 by Sir Frederic Kenyon in tho presence of the Vice-Chancellor, Mr. G. S. Gordon, president of Magdalen College, and a large assembly of distinguished guests. Sir Frederic, speaking as an old friend of Prof. and Mrs. Griffith, said that never had he known a man more single-minded and more tolerant of the work of others than Prof. Griffith. The Griffith Institute would fill one of the great gaps in the equipment of the archæologist. The Vice-Chancellor and Mr. E. T. Leeds, keeper of the Ashmolean, also paid generous tribute to the memory and work of Mr. and Mrs. Griffith. The building in which the Institute is housed is of four floors, erected to the design of Mr. E. Stanley Hall. Three floors are allotted to Egyptology and Assyriology, while the ground-floor is given up to other activities of the Museum. The greater part of the Griffith library is housed in the Institute, and accommodation is provided for the professor of Egyptology and the reader in Assyriology. Space is available for the compilation of the topographical bibliography of Egyptian hieroglyphic texts and other research work, while a large store-room will provide for the Egypt Exploration Society's collection of papyri, which has been transferred from Queen's College, and the collections of ostraka and other material used for purposes of teaching. The University's collection of cuneiform tablets will be arranged in the rooms devoted to Assyriology.

\section{Proposed Museum of Romano-British Archæology}

Lord Eustace Percy, Rector of the Newcastle Division of the University of Durham, has issued an appeal for funds for the erection of a Museum of Romano-British Archæology, devoted to the area of the Roman Wall at Newcastle-on-Tyne, in connexion with the University of Durham. The proposal arises out of a recommendation of the Standing Commission on Museums and Galleries made two years ago, which had in view the need both of facilities for study of the area of the Wall and also of the requirements of the magnificent collections of Romano-British antiquities belonging to the Society of Antiquaries of Newcastle, the main source of information concerning the Roman frontier in Britain and settlements adjacent, which have been brought together in the course of the last hundred years, and are now somewhat inadequately housed in the medieval Black Gate of the Castle. The Society has generously expressed its willingness to place its collections at the disposal of the University for this purpose, subject to certain conditions. Although the erection of such a museum had been contemplated in the projected building scheme of the University, it had been set aside for the moment in view of more urgent needs; but it has now been brought within the range of practicable proposals by the offer of a grant of $£ 5,000$ from the University Grants Committee, provided the further sum required to make up the total estimated expenditure of $£ 20,000$ is raised within a period of two years. The Museum will not be confined to Romano-British antiquities but will include all relies obtained from the area of the Wall, both prehistoric and of post-Roman date down to the Norman conquest. Subscriptions are being received by Lord Eustace Percy at King's College, Newcastle-on-Tyne, 2.

\section{Testing Electric Meters and Appliances}

THe opening of large extensions by the Lancashire Electric Power Co. on January 16 of its department for testing electric meters and electric appliances shows how rapidly this branch of the firm's work is developing. That part of the firm's revenue which depends upon meter registrations now exceeds a million pounds per annum, while the number of meters issued has almost quadrupled during the last nine years. A great deal of the extra work done is in connexion with household appliances, offered by the firm on hire and hire-purchase terms. These are installed and maintained by the testing department. The number of domestic appliances connected, such as cookers, water heaters, fires, kettles; etc. increased in number from 400 in 1930 to 10,700 in 1934 and to 38,000 last year. In the last two years, 2,000 thermostatically controlled cookers have been issued to customers. Nearly all the domestic consumers pay on a two-part tariff with a power charge of 0.5-ld. per unit. All meters are tested when removed from service, after which they are reconditioned and certified. A small cleaning room is provided for exceptionally dirty meters, the equipment of which includes a powerful blower and an extractor fan. At the opening ceremony, it was stated that an electricity meter is not only one of the cheapest but also one of the most accurate things the firm has on the market. Since 1936, all cookers offered by the firm have had automatically controlled ovens. Their thermostats are checked for consistency and the enamel is tested for durability. Tests include temperature measurements every 
minute at five different points in the oven; if satisfactory, these tests are repeated with food in the oven. The L.E.P. Co.'s experience is that the most critical practical test of an oven is the baking of plate pies, and the next most critical the baking of bread.

\section{Thermionic Valves as Measuring Instruments}

THE thermionic valve has long been recognized as a useful tool in many branches of science and engineering; but few, with the exception of experimenters, have realized that it can be usefully applied for measurement purposes. Until quite recently, engineers have regarded the valve as being rather an unknown factor and so have been reluctant to rely on it when precision measurements are required. In a paper presented to the Institution of Electrical Engineers on January 6, by Dr. E. G. James, G. R. Polgreen and $\mathbf{G} . \mathbf{W}$. Warren, the principles are outlined of various kinds of valves for the measurement of alternating voltages (including 'slide-back', peak, grid-leak and anode-bend voltmeters) and of voltmeters and electrometers for direct voltages. Methods of measuring very small values of current and power are described. Although the uniformity existing between the characteristics of valves of the same type is not quite perfect, the modern valve gives a very stable performance during its life, more particularly under the operating conditions imposed in measuring devices. Of all valve-measuring devices, the valve voltmeter probably is the most widely used instrument, especially for high-frequency measurements. It is sensitive and it can be designed to absorb negligible power from the source. In normal instrument practice, current is measured either by its magnetic or by its heating effect, and voltage is measured by measuring the current through a known resistance. In the case of instruments employing valves, the converse procedure is adopted. Voltage is measured by its controlling action on the electron current in the valve, while current may be determined by measuring the voltage produced across a known resistance. A simple and inexpensive valve voltmeter can be made to operate from pocket lamp batteries. It makes a useful selfcontained instrument with the general advantage of very high impedance and wide frequency range. The paper is a communication from the Research and Engineering staffs of the General Electric Co., Ltd., the M.O. Valve Co., Itd., at Wembley and the works of the Salford Instrument Co.

\section{Progress of Medical Psychology}

IN an address at a public luncheon arranged by the National Institute of Industrial Psychology on January 18, Dr. J. R. Rees, medical director of the Tavistock Clinic, said that this century has seen very great progress in both the science and the art of psychological medicine. Moreover, in the treatment of neurosis and nervous breakdown and in medicine as a whole, the introduction of the principles of medical psychology in the last few years has brought about a greater change than anything else in medicine. In the basic understanding of the processes of mental disease, much is owed of course to Freud and his followers, but the work of Jung, McDougall, Adler, Rivers and Hadfield - to mention only a fewhas been of an outstanding quality. The medical student can now be taught to understand the human beings with whom he has to deal without the use of any technical jargon and without any exclusive reference to a particular school of thought in psychology. In the actual treatment of the neuroses we are making steady advance. There is evidence from the careful follow-up work which has been done, first of all at the Tavistock Clinic and then at the Cassel Hospital at Penshurst, that approximately 50 per cent of the patients treated, irrespective of the particular method, seem to be permanently relieved and socially adjusted. That is a very satisfactory figure in comparison with the figures for other diseases. More important perhaps than the provision of treatment for the definite neuroses is the fact that through recent research we are coming to realize that many of the illnesses which have always been supposed to be mainly physical, have in fact a very large emotional factor in their causation. Psychological medicine is now coming into its own place in the system of medicine and is showing itself to have the closest possible relation to the problems of general medicine. The General Medical Council has now insisted that medical psychology should become part of the regular training of every medical student.

\section{Flora's League}

Botanists, nature-lovers and those who are concerned for the conservation of the native British flora will be interested to know that it has been decided to continue the activities of Flora's League, the national society for the preservation of wild flowers, trees and ferns, as a memorial to its founder, the late Sir Maurice Abbot-Anderson. Sir Maurice, a distinguished physician, founded the society in 1925 and was its president up to his death, when it had a following of more than twenty thousand members and a wide infuence through the public and school lectures it organized as propaganda for the preservation of the British flora from vandalism and unscientific collecting. Lady Abbot-Anderson has undertaken to carry on her husband's work as president of the League, which is closely associated with the Council for the Preservation of Rural England, the office of which it shares, and an appeal is being made for a fund to continue this work. In a statement on its policy, the League clearly refutes any suggestion of mere sentimentality or crankiness in its methods, for it points out: "There are inevitable economic influences at work which mitigate against the preservation of our wild flora, and with which we cannot quarrel. Building, road-making, drainage, quarrying and the like, must, in the ordinary course of things, proceed. Methods of transport also are more easily available, and bring enormous enjoyment, as well as increased health, to the population". A by-law against the uprooting of any wild plants from roadsides and places to which the public has access, without authoritative 